\title{
Når design af færdighedstræning er udgangspunkt for design af et færdighedslaboratorium i klinisk biomekanik
}

\section{Cita Nørgård}

Pædagogisk konsulent

SDU Universitetspædagogik, SDU

\section{Henrik Hein Lauridsen}

\section{Lektor, Studieleder}

Institut for Idræt og Biomekanik, SDU

\section{Søren Bech}

Underviser

Sygeplejerskeuddannelsen, UC Lillebælt
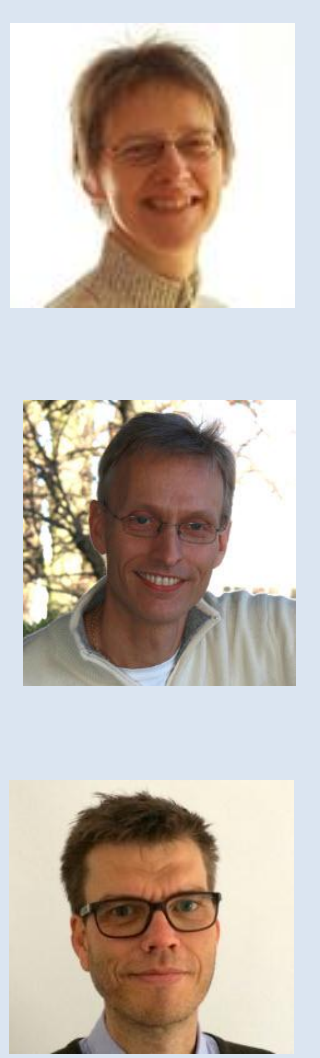


\section{Danish abstract}

\section{På uddannelsen i klinisk biomekanik}

(kiropraktoruddannelsen) er færdighedstræning en betydelig del af undervisningen. Det er vigtigt, at læringsprincipper med aktiverende undervisning og feedback i undervisningen prioriteres højt, da det fremmer de studerendes læring.

Artiklen beskriver, hvorledes vi med udgangspunkt i de studerendes læringssituation designer inddragelse af video i undervisning og feedback.

Videomediet skal bruges direkte i og som forberedelse til undervisningen samt til hjemmeopgaver. Formidling af optagelserne skal kunne ske både mellem underviser og studerende og mellem studerende indbyrdes. Videooptagelserne gøres til genstand for direkte feedback til studerende. De er også udgangspunkt for peer feedback mellem studerende både i og udenfor den planlagte undervisning.

IT-design og undervisnings- og studieprocesser skal tilgodese både den pædagogiske strategi på det sundhedsvidenskabelige fakultet og SDU's bærende principper for god undervisning. Vi har arbejdet ud fra en tilgang, hvor laboratoriet først designes, efter de ønskede læringsscenarier var beskrevet. Dette sikrer at IT-udstyr og opsætning tilgodeser netop de ønskede undervisningsscenarier. Artiklen fokuserer på under inddragelse af eksisterende viden at sammenholde de pædagogiske og undervisningsteknologiske muligheder i forbindelse med udarbejdelse af lokalets design.

\section{English abstract}

Skill training is an important part of the teaching at the education in biomechanics. It is important that the principles of active teaching and learning and feedback have a high priority as it provides deep learning among students.

This article describes how we design facilities to include the videomedia in teaching and feedback taking the standpoint of student learning. Videos shall be used directly for preparation for classes, in the skill-training laboratory and also when students produce assignments. Teachers and student will share the recordings and provide feedback directly on the students' recordings. Also peer feedback between students in lessons and between lessons will be part of the teaching. 
IT-design, teaching and study processes must live up to the pedagogical strategy at the Faculty of Health and the underlying principles for active teaching and learning at SDU. Our approach is that at first we designed the teaching and learning scenarios and then we designed the new laboratory hard- and software taking the teaching and learning scenarios into account. This procedure was to ensure, that the IT equipment was "primed" to ensure that the pedagogical approaches can be reached when the laboratory come into use. Here we focus on how the existing knowledge and experiences is used to define the learning scenarios, technology and laboratory design.

\section{Indledning}

De studerende skal på både bachelor- og kandidatuddannelser blandt meget andet lære, hvordan man manuelt behandler patienter med præcise greb og samtidig kommunikerer med patienter i behandlingssituationen. Vi arbejder i denne artikel med undervisning i manuelle færdigheder i kiropraktoruddannelsen.

Erfaringer fra et pilotprojekt viser, at studerende er meget tilfredse med at kunne se og bruge videoer produceret af undervisere. Både til deres forberedelse og til deres øvelser i færdighederne (1). Atter andre erfaringer fra SDU viser, at de kollaborative muligheder i lokaler med moderne kommunikative faciliteter er meget eftertragtede både hos undervisere og hos de studerende, der færdes i lokalerne. På SDU arbejdes der i forvejen med pædagogisk anvendelse af videokommunikation indenfor færdigheder i idrætsstudiet, og vi ønsker at bruge den viden og software, der er udviklet her (2). Med udgangspunkt i disse samt internationale erfaringer (3) har vi valgt at renovere færdighedslaboratoriet på Institut for Idræt og Biomekanik (IOB), så det ligger i tråd med de ønsker og krav, der er til en tidssvarende undervisning i biomekaniske færdighedslaboratorier. Videooptagelser spiller internationalt en større og større rolle i forbindelse med færdighedstræning - ikke mindst på medicinstudiet. Litteraturen på området vokser støt og vi har i dette initiativ mulighed for at læne os op af flere studier, der anvender video i færdighedsundervisning.

Det har været et markant ønske fra studerende og fra undervisere, der bruger færdighedslaboratoriet, at studerende på store hold bedre skal kunne se de viste instruktioner, og at underviserne bedre skal kunne give feedback til studerende. Samtidig vil vi gerne understøtte de studerendes egne studie- og læreprocesser i de læringssituationer, hvor der ikke er en underviser tilstede.

Den pædagogiske strategi fra det sundhedsvidenskabelige fakultet (4) og de bærende principper ved SDU (5) spiller markant ind på valget af pædagogisk tilgang. Tilsammen lægger disse pædagogiske strategier en linje, hvor vi specielt vægter feedback og prioritering af gennemtænkte aktiverende læringsaktiviteter.

Afklaringen af, hvad teknikken skal kunne, er derfor vigtig, inden vi beslutter endeligt, hvilken løsning, der skal installeres i lokalet. Dette giver en præcis, pædagogisk argumenteret kravspecifikation, og først derefter skal der ske en etablering af IT løsningerne. Løsningerne forventes etableret i sommeren 2014.

Vi benytter i denne artikel termen "færdighedstræning" om "manuel behandling af patienter". Til sidst i artiklen diskuteres færdighedstræning indenfor andre fagområder i relation til de diskuterede undervisningsteknikker. 


\title{
Det læringsmæssige design
}

\author{
De pæedagogiske principper bag læringsdesignet \\ Ved det Sundhedsvidenskabelige fakultet på SDU har man vedtaget en pædagogisk strategi.
}

Den bygger dels på FAIR-principperne (6)

Feedback

Aktivitet i undervisningen

Individualisering

Relevance

og dels på constructive alignment - princippet, der beskriver sammenhængen mellem læringsaktiviteter, læringsmål og prøveform (7). Ved SDU har man endvidere vedtaget "De bærende principper for aktiverende undervisning og aktiv læring ved SDU", som beskriver, at alle interessenter i uddannelserne skal yde deres til, at undervisningen bliver en aktiv tilegnelsesproces for de studerende.

\section{Udvikling af læringsdesignet}

Som inspiration til, hvordan tænkningen kan udmøntes i praksis, blev der arrangeret en workshop for studieleder, udvalgte undervisere samt pædagogisk konsulent og elæringskonsulent. Der blev tænkt "ud af boksen", og derefter udvalgte og beskrev studieleder og undervisere, hvordan de tre principper for undervisningen kan udmøntes. Overvejelserne manifesterer sig i 4 udvalgte indsatspunkter.

\section{Udvalgte af indsatspunkter}

Når FAIR, constructive alignment og aktive læringsprocesser diskuteres i forhold til færdighedstræning, fremstår følgende centrale indsatspunkter, som skal skinne igennem undervisningsscenarierne

- Feedback til studerende - hvordan kan vi fremme feedback $i$ vores undervisningsmodeller?

- Åbne muligheden for at give både synkron og asynkron Feedback på studerendes træningssituationer i færdighedslaboratoriet.

- Optimere muligheden for at studerende kan give peer Feedback på hinandens optagelser vedr. indøvelse af færdigheder.

- De studerendes egen studieaktivitet - hvordan kan vi facilitere den?

- Optimere studerendes mulighed for at forberede sig Aktivt til lektionerne ved hj. af instruktions- og forelæsningspodcasts. Studere Individuelt og i grupper - også med video som læringsredskab - og have muligheden for at dele egen udvikling af færdigheder med underviser og medstuderende.

- Hvordan kan vi styrke "just in time" instruktionerne, så den Individuelle studerende får det rette input på det rigtige tidspunkt?

- Instruktionsvideoer bruges fleksibelt i undervisningslokalet (under $\varnothing$ velser på storskærme) og uden for lokalet (på en videoplatform, som kan tilgås på alle typer hardware). Dermed skabes maksimal Relevans og Aktivitet.

- Hvordan udnytter vi laererressourcen mest hensigtsmaessigt i tilstedevarelsestimerne?

- Kvaliteten af instruktioner i færdighedstræningen sikres ved at bruge skærmene i laboratoriet mest mulig i små grupper, som er ledet af en underviser. Det giver rum til Aktivtet og Feedback i undervisningstimerne og minimerer behovet for demonstrationer for store grupper af studerende. 
Disse fire indsatspunkter kan overføres til følgende udviklingsmodel for lokalet (figur 1). Derved sikres at de pædagogiske indsatspunkter afspejles i specifikation af særlige krav til it faciliteterne (se Figur 1).
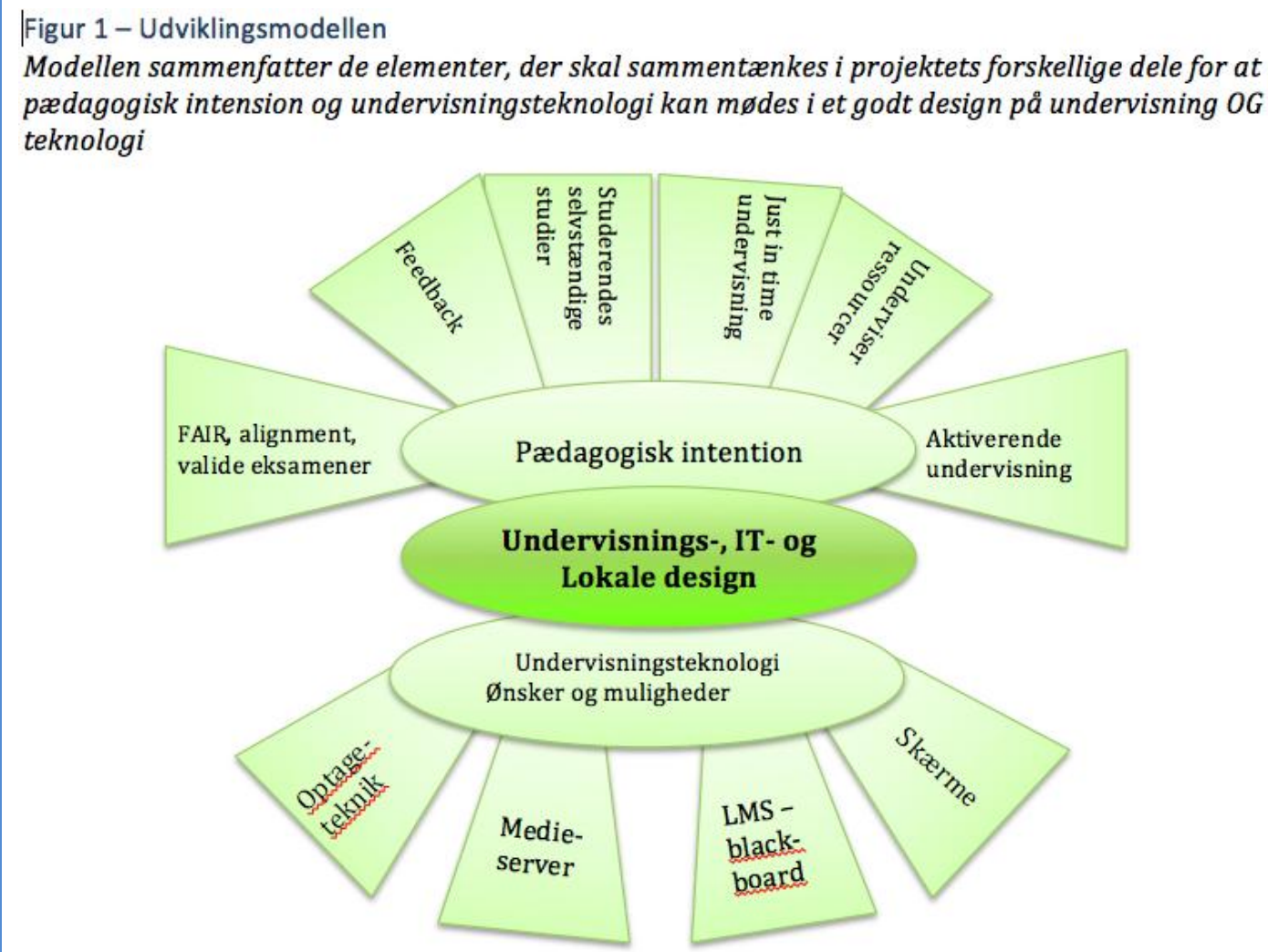

Figur 1

\section{Fire undervisnings-scenarier}

I litteraturen beskrives to overordnede kategorier af formidling, når det gælder inddragelse af video i undervisning. På den ene side videoinstruktioner og demonstrationer $(1,11,9)$ og på den anden side studerende, der optager video som en del af undervisningsopgaver $(12,13,14)$. Den første kategori er oftere behandlet end den anden - sikkert fordi undervisning i videregående uddannelse stadig hænger relativt fast i et formidlingsparadigme, hvor underviseren besidder viden og formidler den til de studerende (også nu i podcasts!), og ikke i samme omfang har assimileret kollaborativ og konstruktivistisk læringstænkning, som undervisning på lavere uddannelsesniveauer har det. Et grundlæggende ønske med dette arbejde er, at didaktiske ideer som deep learning, og collaborative learning samt FAIR-princippet skal virkeliggøres i anvendelsen af laboratoriets IT faciliteter. Constructive alignment spiller også en væsentlig rolle ud fra prioritering af velargumenterede læringsaktiviteter, som harmonerer med udprøvning af færdigheder i OSCE eksamen. 
Figur 2 illustrerer de forskellige faser, som arbejdet i det nye færdighedslaboratorium tænkes at rotere i. Figuren tager blot fat i inddragelsen af videomediet, men dette indarbejdes naturligvis med andre undervisningsaktiviteter i tilknytning til færdighedstræningen.

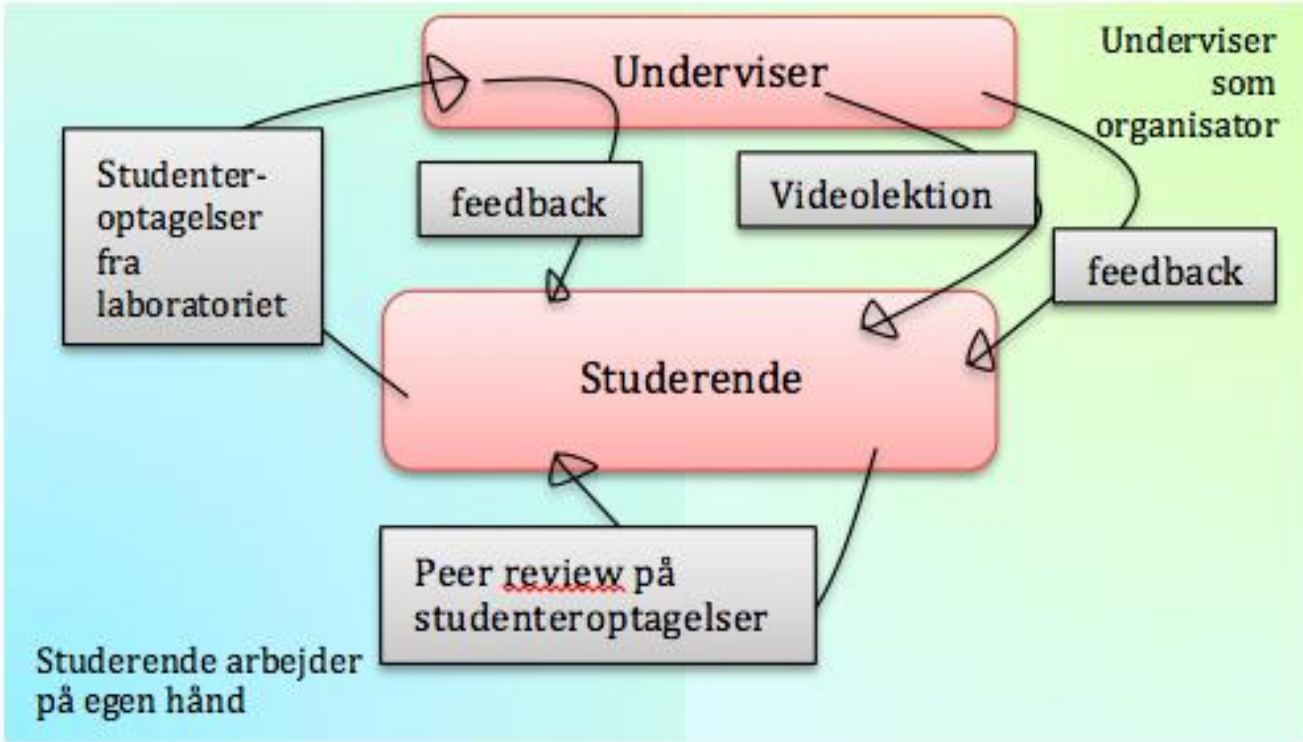

Figur 2. scenarier for studerendes læring

De studerendes læring og samspil med hinanden og underviser kan illustreres igennem rotationer med disse forskellige læringsaktiviteter (i det grønne område er underviseren organisator og i det blå område er den studerende organiserende aktør)

Maloney et al. 2013 (8) fremhæver ved sammenligning af forskellige undervisningsscenarier forskellen mellem "delivering content" (tilstedeværelsesundervisning og videolektioner) og "reflected content" (tutor, peer- og self assessment på basis af studerendes egne videooptagelser). Feedback foregår i dette studie via e-læringsplatformen blackboard. To markante anker hos studerende i Maloneys studie, som vi også genkender det hos os, er hhv. mangel på mulighed for at se detaljer i patienthåndteringen ved demonstrationer i tilstedeværelsesundervisningen og manglen på kommunikation med underviser, når der formidles via videolektioner. Det skulle rotationer i undervisningsformerne gerne kunne rette op på i de nye lokaler, med øget feedback og demonstrationsmuligheder via skærmene.

De relevante undervisningsaktiviteter, som underviserne i færdighedslaboratoriet har fundet frem til i det pædagogiske baggrundsarbejde, kan beskrives i fire overordnede scenarier. Det er vigtigt i forhold til implementeringsprocessen af ny teknologi, at underviserne især i startfasen kan genkende deres egen praksis i beskrivelserne. På længere sigt vil praksisbeskrivelserne muligvis udvikle sig i en retning, der nærmer sig kategoriseres som "skills lecturing", "peer - and self reflection", "formative evaluation" og "practicing/self studies" og indholdsmæssigt udvikles til de nye praksisser. Øvelsen har også den positive effekt, at det vil være meget nyttigt for de studerende, at der er klart formulerede formål med aktiviteterne, da det også vil være nye undervisningsformer for dém. 


\begin{tabular}{|c|c|}
\hline Praksisbeskrivelser & Formål \\
\hline $\begin{array}{l}\text { 1. Videolektioner med og } \\
\text { uden PowerPoint }\end{array}$ & $\begin{array}{l}\text { Formålet med videolektioner med PowerPoint er: } \\
\text { a) At formidle teoretiske emner før gennemgangen af en } \\
\text { færdighed } \\
\text { b) At formidle udførelsen af en færdighed }\end{array}$ \\
\hline 2. Gruppearbejde med video & $\begin{array}{l}\text { Formålet med gruppearbejde med video er: } \\
\text { a) At udvikle kvaliteten ved udførelsen af specifikke } \\
\text { færdigheder: } \\
\text { 1. Behandler og patient positionering } \\
\text { 2. Flow og struktur ved udførelsen } \\
\text { 3. Håndelag (fx hastighed og amplitude) } \\
\text { 4. Patient håndtering } \\
\text { 5. Verbal og non-verbal kommunikation } \\
\text { 6. Professionalisme } \\
\text { b) At udvikle selvrefleksion ved udførelsen af en færdighed } \\
\text { c) At udvikle en personlig tilpasning ved udførelsen af en } \\
\text { færdighed }\end{array}$ \\
\hline $\begin{array}{l}\text { 3. Løbende supervisering } \\
\text { med video }\end{array}$ & $\begin{array}{l}\text { Formålet med den løbende supervisering med video er: } \\
\text { a) At foretage en formativ evaluering af de opnåede } \\
\text { færdigheders kvalitet i forhold til: } \\
\text { 1. Behandler og patient positionering } \\
\text { 2. Flow og struktur ved udførelsen } \\
\text { 3. Håndelag (fx hastighed og amplitude) } \\
\text { 4. Patient håndtering } \\
\text { 5. Verbal og non-verbal kommunikation } \\
6 . \text { Professionalisme } \\
\text { b) At udvikle selvrefleksion ved udførelsen af en færdighed } \\
\text { c) At udvikle en personlig tilpasning ved udførelsen af en } \\
\text { færdighed }\end{array}$ \\
\hline $\begin{array}{l}\text { 4. Øvning på egen hånd med } \\
\text { video }\end{array}$ & $\begin{array}{l}\text { Formålet med at } \emptyset \text { ve på egen hånd med video er: } \\
\text { a) At udvikle kvaliteten af specifikke færdigheder ved } \\
\text { selvrefleksion af: } \\
\text { 1. Behandler og patient positionering }\end{array}$ \\
\hline
\end{tabular}




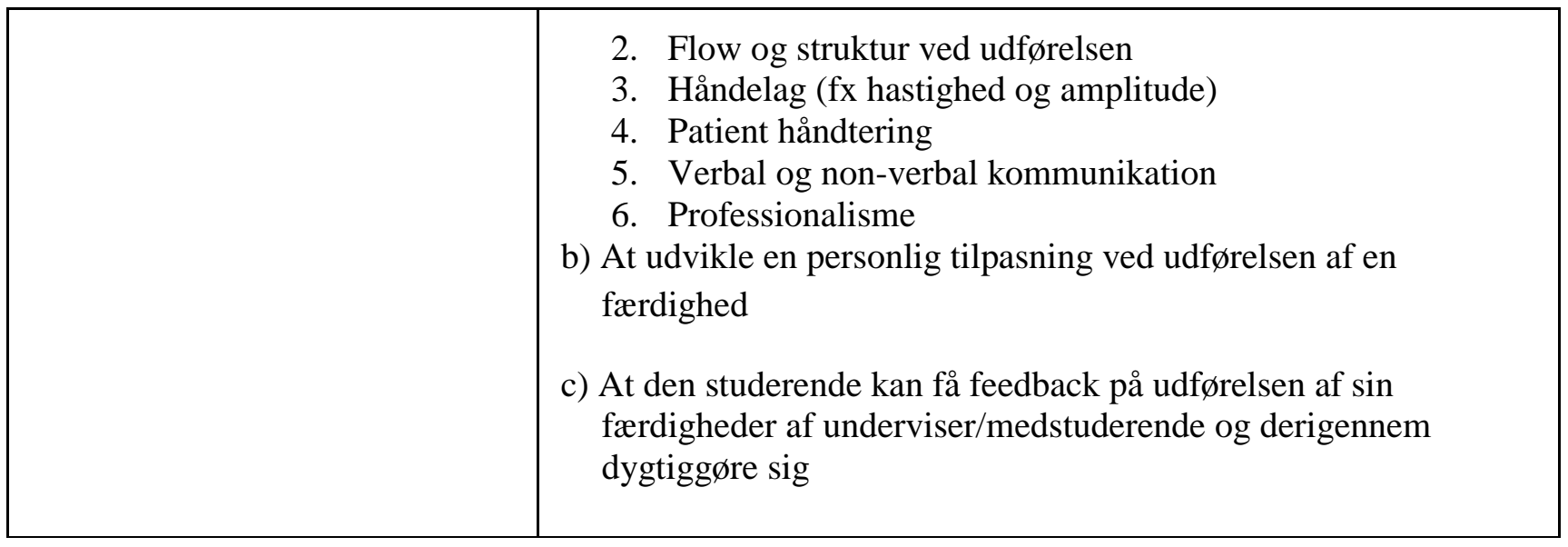

Tabel 1 De fire undervisningsscenarier

Rotationerne (illustreret i figur 2) kan beskrives som fire undervisningscenarier, der tager højde for de fire indsatspunkter. I appendix 1 ses de fuldstændige beskrivelser og korrelation med de beskrevne pædagogiske principper.

For at kunne perspektivere og begrunde de fire undervisningsscenarier i tabel 1 mere detaljeret, beskriver vi her kort litteraturen, som har givet inspiration til vores tanker om undervisningen.

Videolektioner tænkes at indgå i stedet for eller i hvert fald at supplere instruktioner on location, og skal styrke de studerendes fokusering og forståelse forud for undervisningen. On location skal der derfor blive meget bedre tid til at arbejde med den enkeltes mestring af færdighederne via face-toface feedback, hvilket skaber det spørgeforum, som studerende hyppigt værner om, når vi indfører videolektioner.

En ret stor undersøgelse, som for nylig blev foretaget i Korea, undersøgte brugen af en database med videoinstruktioner (10). Den viste for det første, hvor vigtigt det er, at indarbejde videoinstruktioner i selve curriculum f.eks. gennem velbeskrevne e-læringsaktiviteter, så det ikke blot er en tilgængelig læringsressource. For det andet understreger de studerende i undersøgelsen vigtigheden af, at de har mulighed for at diskutere spørgsmål med underviserne. Også i en undersøgelse på Det Sundhedsvidenskabelige Fakultet på Syddansk Universitet udtaler studerende, at det er vigtigt at bibeholde den direkte kontakt til underviser $(11,1)$. Den direkte adgang til en stribe videoer af færdigheder, som den studerende skal mestre, beskrives i det koreanske studie som rigtig nyttig i forhold til nærmest alle dele af studieprocesserne og eksamensforberedelsen. Dette synspunkt understøttes også af studenterundersøgelser SDU $(11,1)$.

Der er efterhånden mange studier, som har undersøgt nyttigheden af at anvende videoforelæsninger - også af færdigheder - som læringsressource (f.eks. (9)). Evidensen for læringseffekten i undersøgelserne dokumenteres som regel ikke med bedre eksamensresultater, men beskrives via de studerendes vurdering af "selvestimeret læringseffekt" - deres vurdering af videopodcasts som nyttig læringsressource og en mærkbar øget motivation. De studerende er glade for mediet og sætter stor pris på at kunne gentage videoerne et ubegrænset antal gange, og at kunne spole og køre frem i forskellige tempi. I timerne beskrives, at paratheden blandt studerende er højere, når de har set videoforelæsninger før færdighedsundervisningen. Endnu mere effektivt 
kan dette blive, hvis det også kombineres med e-læringsopgaver som e-tests eller online spørge/diskussionsfora i et stærkt didaktisk design $(2,11)$.

Studenteroptagelser. Den anden side af litteraturstudierne beskriver undersøgelser af, hvordan studerende har produceret videoer som en del af deres undervisning. Enkelte af disse inddrager eksamensresultater som måleparameter, og Lazzari 2009 (12) finder hos en gruppe af fuldtidsstuderende en lille signifikant forbedring af eksamenspræstationen. Generelt set er der også i denne forbindelse andre observationer end eksamensresultater, man støtter sig til, for at udtrykke det læringsmæssige benefit af studenteroptagelser i undervisningen.

Også elever i folkeskolen drager læringsmæssig fordel af at diskutere færdigheder og give feedback til hinanden på basis af videooptagelser med dem selv. Dette beskrives meget flot i et studie af den specialudviklede software, som også skal bruges i færdighedstræningen i det nye biomekaniklaboratorium. For at eleven kan bevæge sig fra læring på basis af instruktion til læring via refleksion og kollaboration, er der brug for et didaktisk design. Elbæk 2012 (2) konkluderer således, at det er meget vigtigt, at der er tænkt et synligt læringsdesign $\mathrm{i}$ undervisningen. Det er vigtigt, at de studerende ved, hvad de skal kommentere på, har en rubric for peer på medstuderendes uploads og f.eks. ved hvilke tidsrammer, der er gældende. Et styret didaktisk design er vigtigt - i det mindste indtil mål, læringsniveau, procedurer og forventninger er indarbejdet i læringsfællesskabet mellem studerende og undervisere. For at skabe synergi i disse processer er det vigtigt, at underviserne har diskuteret læringsscenarier og er enige om nogle principper og scenarier for, hvordan teknologien kan indgå i undervisningen.

I et studie af færdighedstræningen (i kommunikationsfærdigheder), hvor studerende havde video submission med peer-to-peer som en fast del af curriculumaktiviteterne registreredes det, at udover en signifikant forbedring i performance (på 7,5\% i karakteren) ved den pågældende stand i OSCE-eksamen, så var der andre positive sideeffekter med øvelsen. Underviserne kunne spotte nødvendige indsatsområder ud fra de videoer som de studerende optog - just in time teaching bliver muliggjort. Undervisere kunne endvidere følge de studerendes professionelle udvikling igennem kurset (13).

I vores læringsdesign er det planen, at de studerende i deres selvstudier af færdighederne optager udførelse og lægger disse på medieserveren, hvor både de selv (self assessment), andre studerende (peer assessment) og underviserne kan give feedback. Dette kan dels foregå i faste læringsdesign og dels foregå i mere selvdrevne processer. Det er ikke altid studerende behøver at involvere underviseren, og ofte vil man sikkert lige tjekke med nogle medstuderende, inden man beder om underviserens feedback. Dette gavner ikke kun den, der udfører færdigheden, men er lige så nyttigt for den der fører kameraet, og de, der tjekker kvaliteten af det udførte, da alle de implicerede skal reflektere over hvilke kvalitetskriterier, der lægges over en veludført færdighed.

Også self-assessment har vist sig at være gavnlig for læringseffekten. F.eks. konkluderes der i et studie af self-assessment i kommunikationsundervisning (14): 


"first-year pharmacy students had
difficulty self-assessing, and video
review increased their perception
of skill achievement. A curriculum
should include opportunities for
students to develop self-assessment
skills early in the program, and this
should be reinforced throughout
the curriculum."
difficulty self-assessing, and video review increased their perception of skill achievement. A curriculum should include opportunities for students to develop self-assessment should be reinforced throughout the curriculum."
På basis af de fire indsatspunkter, de fire praksisscenarier og litteraturstudierne konkluderer vi, at der vil vise sig et naturligt flow i undervisningen, som i forskellig grad trækker på scenarierne og varierer mellem selvstændigt arbejde og mere lærerstyrede processer - både i timerne og udenfor disse (Figur 3).

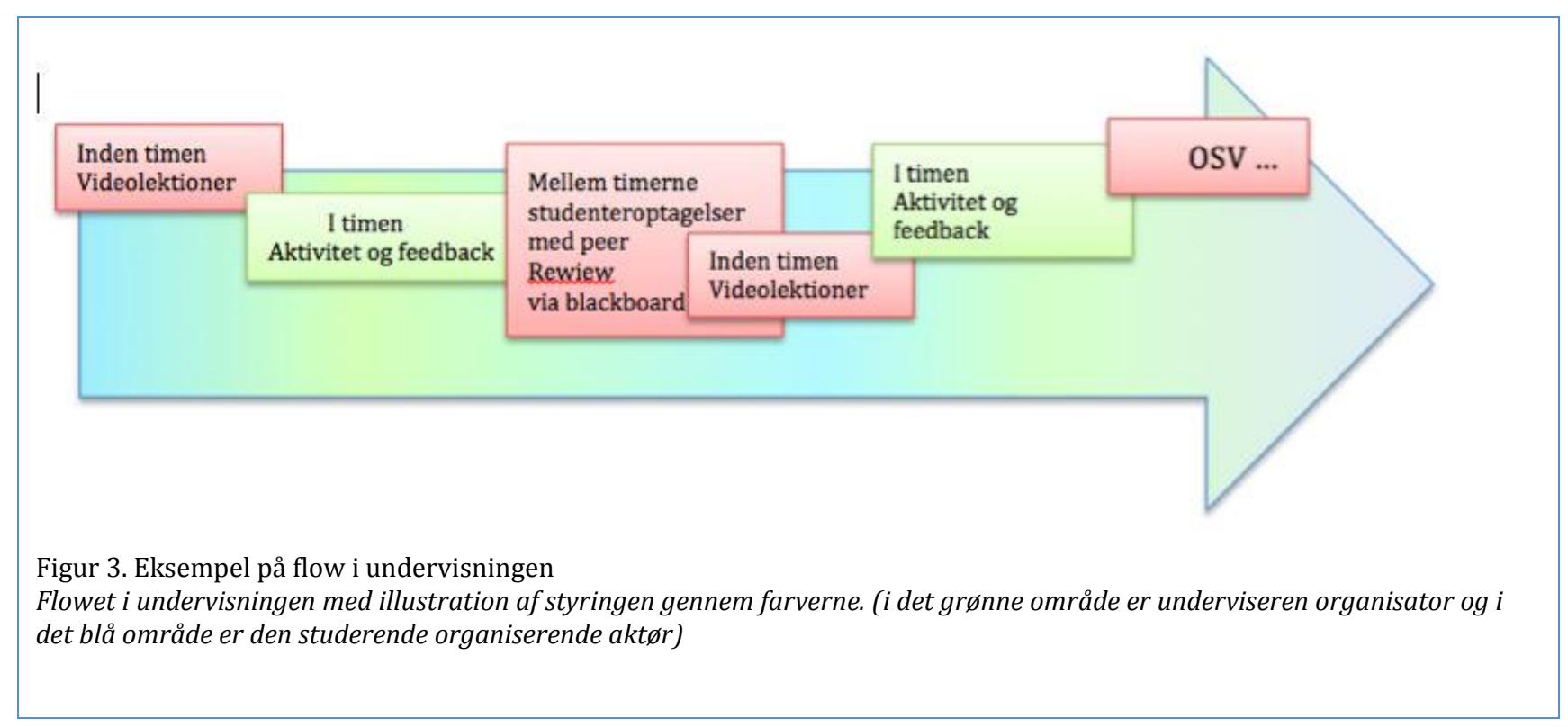

Når underviserne modellerer deres forløb, skal de tænke e-læring og videomediet ind i undervisningsdesignet, så videolektioner går fra at være "en læringsressource, som understøtter selvstudier" til at være en integreret læringsressource.

Desuden skal studerendes videooptagelser struktureres i forhold til selvstændige gruppearbejder og feedbackformer (peer, tutor og self-assessment), så optagelserne indgår aktivt i undervisningen og vidensudviklingen til højere læringsniveauer / deeper learning.

Vægtningen mellem og integration af selvstudier af færdighederne og underviserstyrede aktiviteter vil blive en interessant dimension at studere nærmere på basis af laboratoriets muligheder. Inspiration hertil kan findes i et studie af sutur-færdigheder på University of Toronto, hvor man varierede graden og anvendelsen af læringsressourcer for medicinstuderende, der skulle opnå færdigheder i suturering (15). Denne slags studier og lignende studier, hvor motoriske færdigheder udvikles, vil det være interessant at inddrage i de konkrete didaktiske designs. 


\section{Teknologiske muligheder}

Traditionelt set er forskellige typer af færdighedstræning foregået efter det klassiske "mesterlæreprincip". Typisk undervises en given færdighed i grupper af studerende, der observerer en erfaren lærer. Dette princip bliver i højere og højere grad udfordret af nye teknologiske muligheder med videoproduktion, hvor de studerende også på eget initiativ opsøger videoer for at studere disse. Af den grund udviklede vi de didaktiske ideer til at passe med en teknologisk indretning, som både tilgodeser, at underviser kan optage og udgive kvalitetsvideoer, samt at studerende kan optage og få feedback på øvelsesseancer. Samtidig var der et meget dyrt tilbud, der skulle ændres til projektets økonomiske råderum, så alle indretningsmæssige bolde var oppe i luften.

Figur 4 - Udviklingsmodellen

Den røde pil gennem udviklingsmodellen illustrerer arbejdsprocessen fra det didaktiske design til et egentligt IT design.

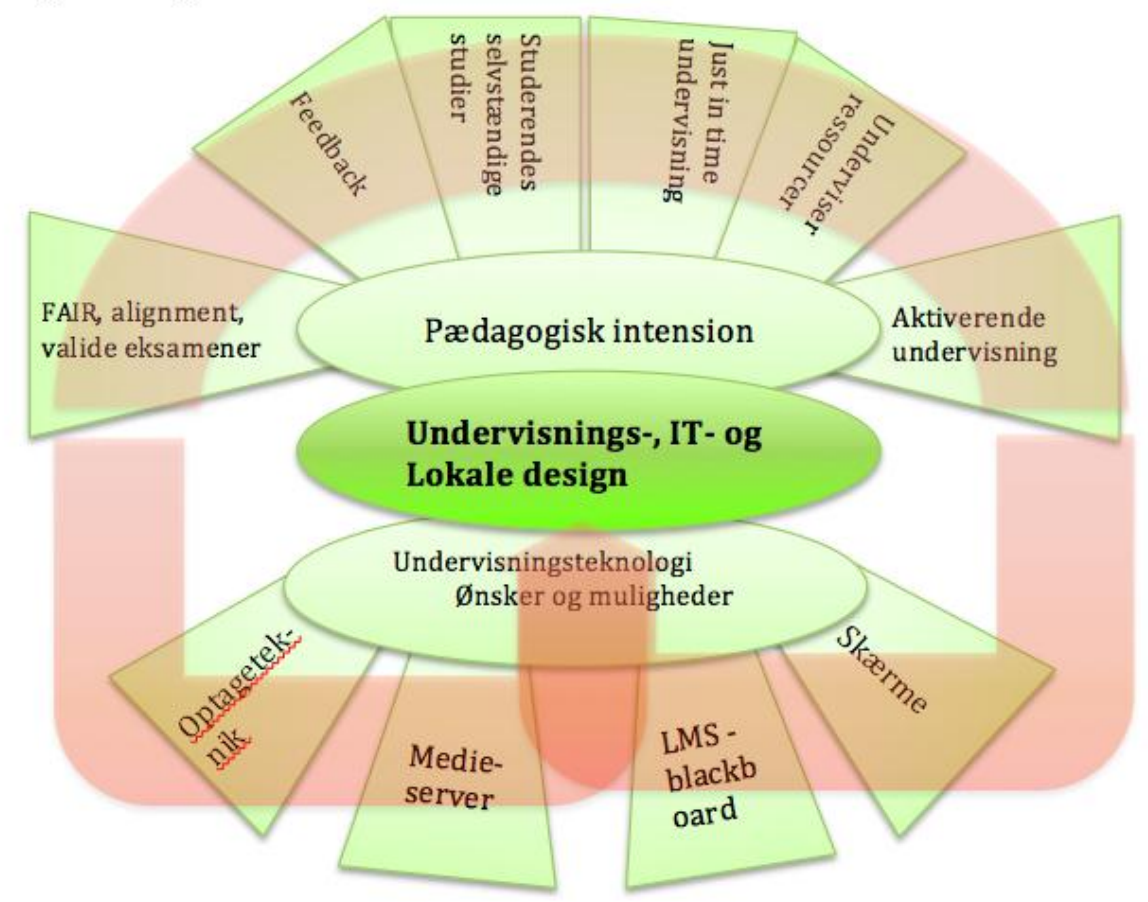

Figur 4

Som illustreret i figur 4 blev næste øvelse derfor at kigge på IT- løsninger, hvor de fire indsatsområder og de pædagogiske principper i figurens øverste del kunne integreres i lokalets endelige design.

Der blev dels kigget på de teknologier, der var til rådighed og dels på "specifikationen af software og de teknikske krav", som det blev specificeret ud fra scenarier og de pædagogiske intentioner (Dette er beskrevet i appendix 1).

Den hastigt stigende teknologiske udvikling har medført et utal af hard- og softwareløsninger i forhold til videoproduktion, og mange løsninger er efterhånden så billige og brugervenlige, at helt almindelige brugere kan være med uden større vejledning. Hvilken løsning, der er optimal i forhold 
til en given læringssituation, afhænger bl.a. af den pædagogiske linje, men også af det valgte systems teknologiske udviklingsmuligheder, begrænsninger og fleksibilitet. Processen for udvælgelse af et holdbart IT-design for nærværende projekt vil blive beskrevet.

\section{Udviklingen af det tekniske design}

I efteråret 2013 blev der nedsat en IT-gruppe med det formål at udvikle et langtidsholdbart ITdesign af færdighedslaboratoriet, der opfyldte de pædagogiske principper. Gruppen blev sammensat af personer med en bred vifte af kompetencer inden for IT \& video, pædagogik, elæring, projektledelse og undervisning, således at skellet mellem det pædagogisk optimale og det teknologisk mulige kunne optimeres.

Det tekniske design tog udgangspunk i IT-baseret laboratorietræning på uddannelserne i kiropraktik, farmakologi og international business på RMIT i Melbourne og projektrummet Kuben på SDU. IT-gruppen udarbejdede en detaljeret kravsspecifikation af både hardware og software, hvilket baserede sig på følgende elementer:

- Pædagogiske intentioner (workflows relateret til undervisningsscenarierne)

- Lokalets design

- SDUs eksisterende IT-løsninger (trådløst netværk og medieplatform)

Basis for kravsspecifikationerne var, at systemet blev brugervenligt (intuitivt), let gennemskueligt og at udgifterne faldt inden for rammerne af projektets budget.

Kravsspecifikationerne gennemgik løbende justeringer i forhold til feedback fra møder med de studerende, færdighedslaboratoriets undervisergruppe og firmaet bag SDUs medieplatform MediaSDU. Slutresultatet blev en fuld og gennemarbejdet kravsspecifikation til både hardware- og software-delen i projektet.

\section{Valg og fravalg}

De udarbejdede kravsspecifikationer dannede således basis for valg af hardware og udvikling af software. De fire vigtigste elementer var 1) udvikling af medieplatformen, 2) integration med Blackboard, 3) optage- og afspilningsteknik samt 4) brug af storskærme (se figur 4).

Medieplatform. MediaSDU blev valgt som det foretrukne video-læringsmedie af flere grunde. MediaSDU består af et webinterface og app'en DigiUpload. Webinterfacet giver brugerne adgang til deres personlige videoer. Hjemmesiden giver desuden mulighed for kommentering, annotering (direkte på videoerne), tagging og deling. Af sikkerhedsmæssige grunde kan videoerne ikke downloades eller deles på sociale medier. Som en del af projektet blev MediaSDU redesignet for at opfylde de pædagogiske principper og gøre interfacet mere intuitivt og brugervenligt. DigiUpload er en app udviklet til iOS og Android, som gør det muligt for de studerende at optage og afspille videoer på deres egen smartphone og/eller iPad. App'en kommunikerer direkte med MediaSDU, og lukkes app'en eller uploades en video slettes alle lokalt optagede videoer af sikkerhedsmæssige grunde.

Integration med Blackboard. Det blev vurderet, at medieplatformen skulle integreres med SDUs Blackboard system, således at adgangen til MediaSDU blev en del af de studerendes læringsplatform. De studerende kan således tilgå deres egne og delte videoer på lige fod med andre undervisningsdokumenter, som findes på Blackboard. 
Optageteknik. Til optagelse af video valgte vi at bruge kamerafunktionen i iPads af flere grunde. For det første er kvaliteten af optagelserne høj (HD-kvalitet) i forhold til prisen. For det andet virker DigiUpload og MediaSDU uden problemer over SDU's trådløse netværk. For det tredje er iPads fleksible i forhold til installering af nye apps, der kan optimere undervisningen. Sidst men ikke mindst er iPads kendt blandt studerende og intuitive at bruge. Vi fravalgte en løsning med brug af professionelle videokameraer installeret i loftet,

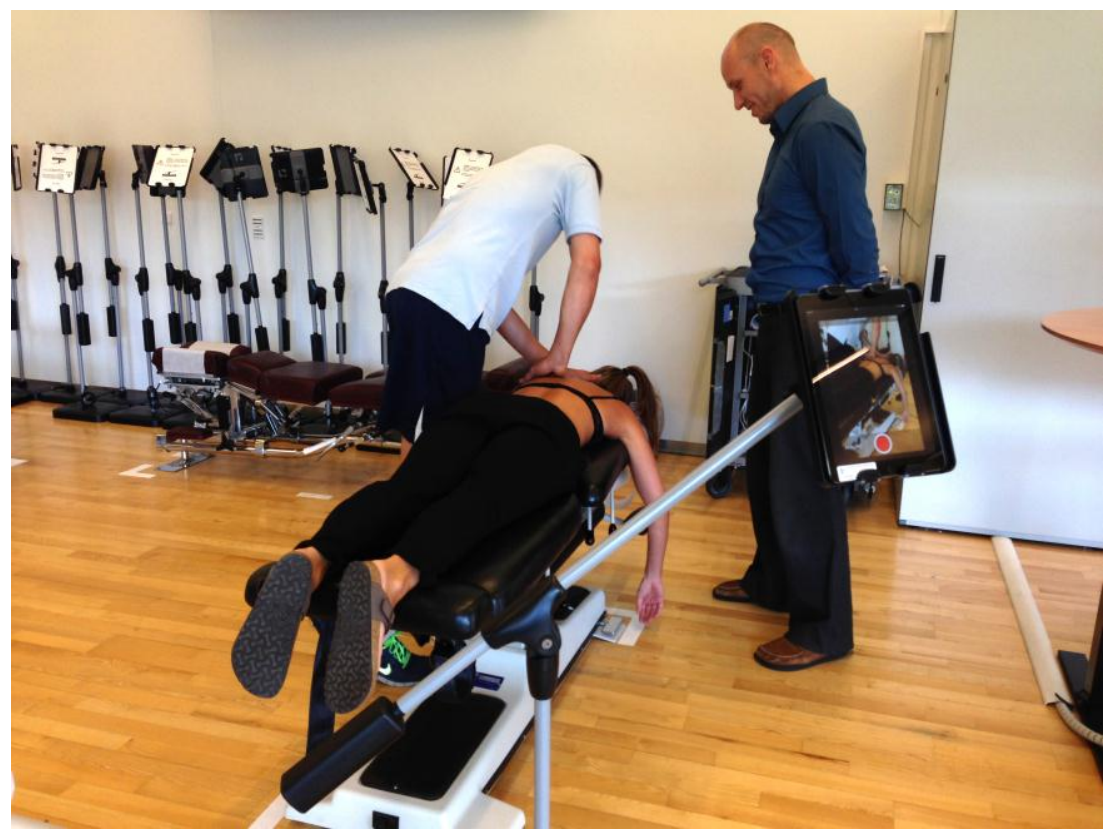
da disse kræver en dyr videomatrix, som skal programmeres, og brugen af dem er kompliceret og besværlig.

Videooptagelser med en iPad laves ved at fastgøre den på et stativ med en fleksibel arm, logge ind på DigiUpload, kalibrere optagevinklen, starte app'en og udføre færdigheden for til sidst at uploade den færdige video til MediaSDU. Alle iPads bliver opbevaret i et opladningsskab.

Brug af storskcerme. Til afspilning af underviserproducerede videoer, blev der installeret en iMac forbundet til seks storskærme via en simpel videomatrix, mens studenterproducerede videoer fra iPads kan afspilles via seks Apple TVs koblet til storskærmene. Der skiftes automatisk mellem afspilning fra iMac og iPads via en switch. Vi fravalgte den originale ide om at bruge split screens til at vise to videoer på én skærm (fx en underviserproduceret video ved siden af en studenterproduceret video). Begrundelsen var, at størrelsen af de to videoer vist side om side blev for lille selv på meget store skærme, og området med sort skærm blev uforholdsmæssigt stort.

Fravalg af bemandet styreenhed. Tidlige udkast til laboratoriets indretning indeholdt en avanceret styringspult med touch skærm. Formålet med styringsenheden var at lave et fleksibelt men brugervenligt system, så alle undervisere havde mulighed for at tilrettelægge deres undervisning efter egne ønsker og behov. Løsningen blev senere fravalgt af flere grunde. For det første var styringspulten en dyr løsning, som krævede avanceret programmering. For det andet går fleksibilitet ofte ud over brugervenlighed, hvilket vi bevidnede i flere andre teknologisk avancerede undervisningslokaler. Valget af en teknologisk fleksibel løsning risikerede at kompromittere brugervenligheden med den konsekvens, at underviserne ikke ville eller kunne bruge lokalets inventar. Sidst men ikke mindst prioriterede vi vigtigheden af den direkte integration af teknologi og undervisning, således at undervisningen bliver styrende af teknologien og ikke omvendt.

Den ovenfor beskrevne hardware løsning giver pædagogisk fleksibilitet samtidig med, at den opfylder kravene til de opstillede undervisningsscenarier (se Figur 5). 
Figur 5. Færdighedslaboratoriet før og efter installation af ny teknik

Før renovering
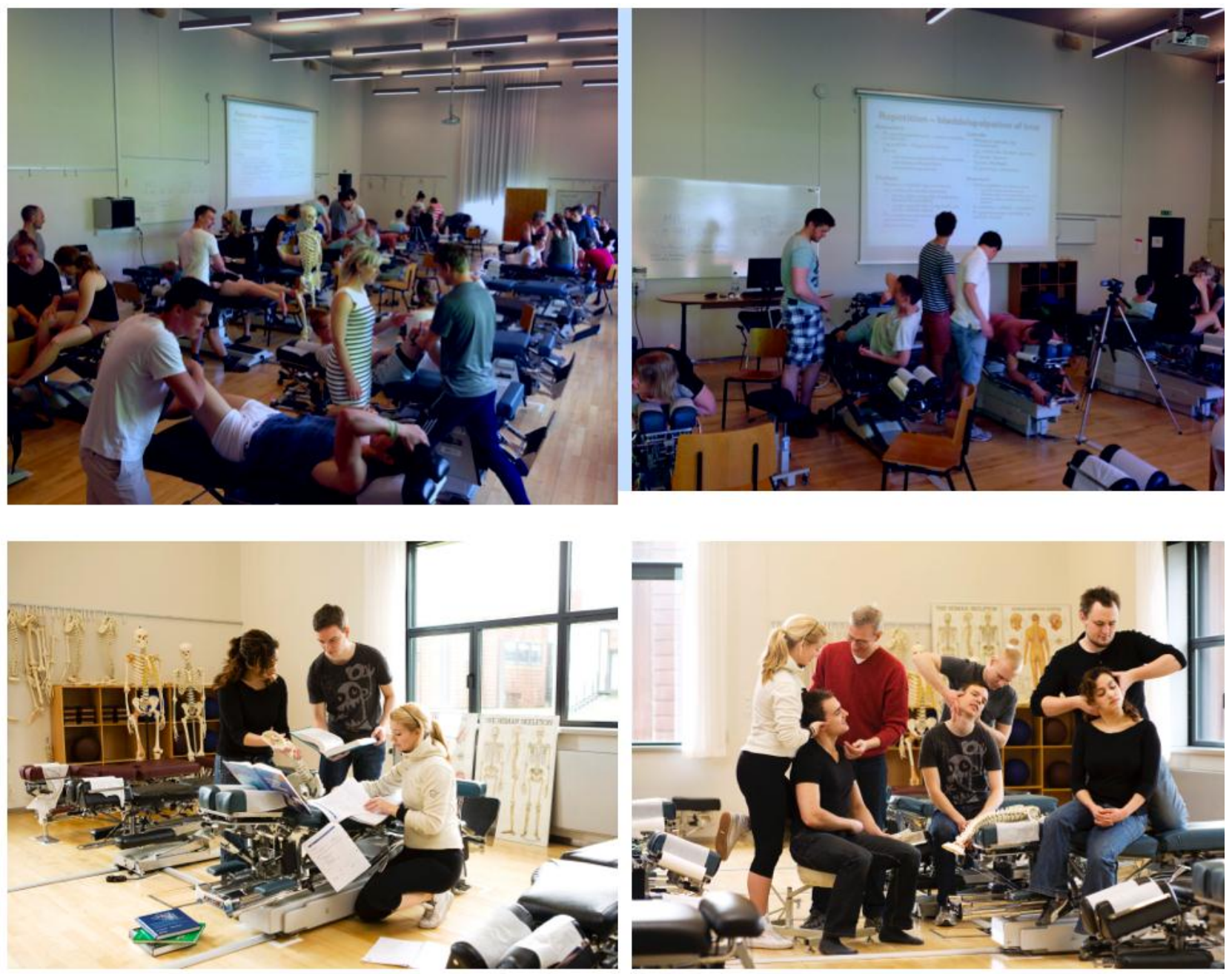
Efter renovering

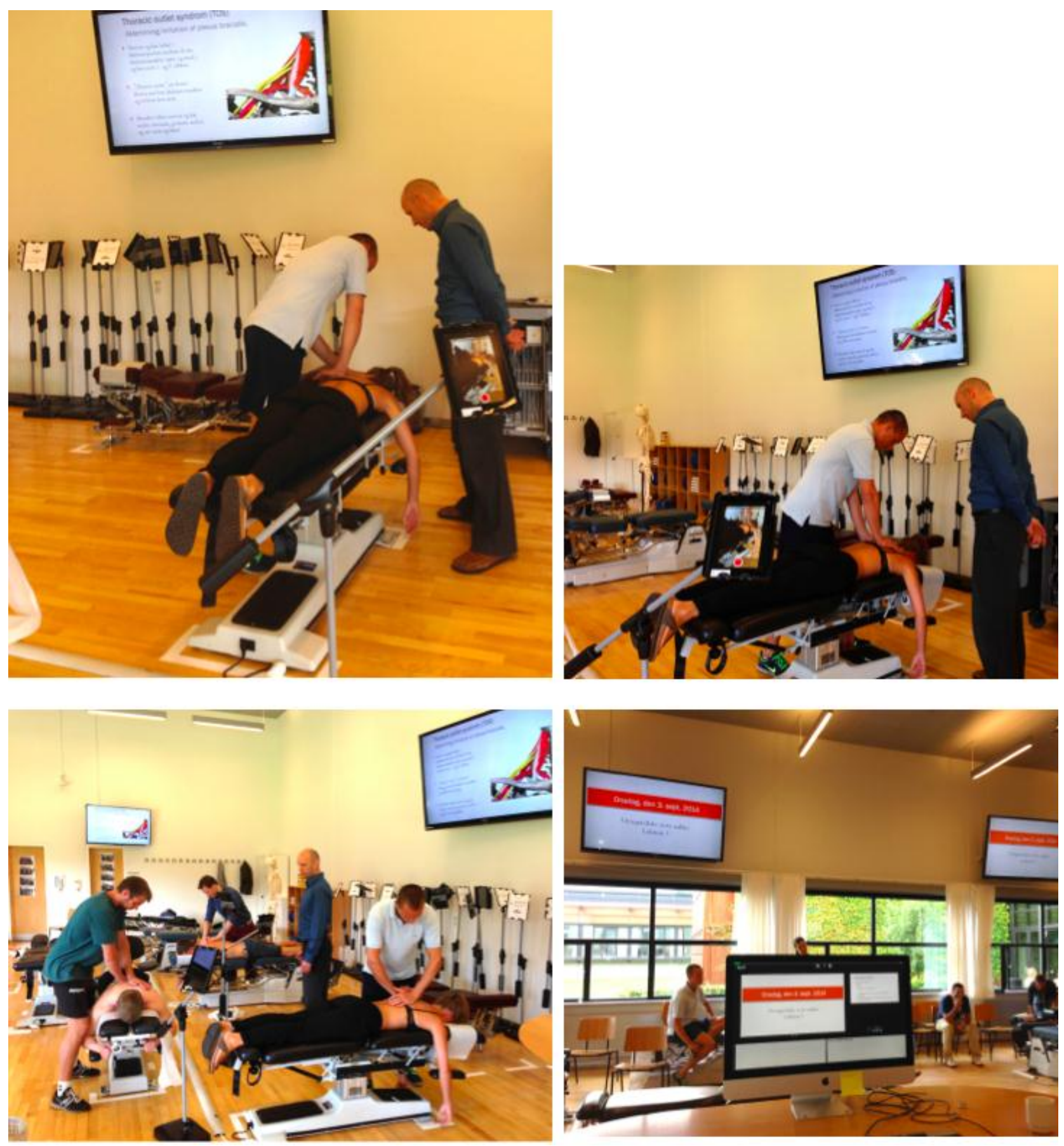




\section{Fremtidsperspektiver og udviklingsmuligheder}

\section{Summative og formative muligheder}

\section{Alignment af eksamen og formativ evaluering}

Med nye læringsaktiviteter og ønsket om alignment udfordres de eksisterende eksamensformer. Med andre ord, skifter man et element har det naturligt indflydelse på de andre. Læringsmålene er fastlagt og har været et holdepunkt i designet af de scenarier, vi ønsker at anvende i færdighedslaboratoriet. Samtidig har vi et ønske om at anvende formative prøver igennem de forløb, de studerende gennemgår. Formålet er at sikre progression frem mod den afsluttende prøve og at medvirke til, at den studerende til enhver tid er klar over, hvilket fagligt niveau han eller hun er på. De formative skal evaluere læringsaktiviteter og have et fremadrettet fokus på, hvad den studerende kan arbejde med og hvordan.

Med dette formål opnår vi to ting. Dels får den studerende feedback på sine læringsaktiviteter og dels kan underviseren bruge resultaterne til at justere undervisningen. Det betyder, at vi kontinuerligt og meget præcist får en viden om, hvorvidt de læringsobjekter, der er udviklet til forløbet, er effektive og opfylder den didaktiske hensigt, de har.

\section{Rubrics}

En "Rubric" er en matrice, der gør læringsmål og evalueringskriterier tydelige. I matricen er yaksen læringsmål der skal opnås og x-aksen en beskrivelse af det niveu, som den studerende opfylder læringsmålet på. Rubrics kan derfor medvirke til at læringsmålene bliver operationelle for både de studerende og underviseren. Niveauet for opfyldelse af målene er her defineret med en tydelig og nu artikuleret viden om, hvad der skal til, for at målet er nået og i hvilket omfang. Derfor vil det være en fordel for både studerende og undervisere, at der på sigt er udarbejdet rubrics for de enkelte læringsaktiviteter. Det vil betyde, at de studerende kan være med til at give peerfeedback, og dermed vurdere den udførte læringsaktivitet ud fra en præcist defineret rubric.

\section{iPad, rubrics og formativ evalluering}

Oplæg, instruktion, øvelser og formative prøver, kræver at underviseren har et overblik over det hold, der undervises når vi tilgodeser "just in time teaching" og individualisering af undervisningen. Et af formålene har derfor været at anvende teknologi til at skabe dette overblik. iPads er som beskrevet en del af den teknologiske løsning i færdighedslaboratoriet. iPads giver studerende og undervisere adgang til Apps, herunder apps til rubrics. Der er flere muligheder for at anvende rubrics på en iPad alt efter formål. Vi har valgt at afprøve en løsning, hvor de studerende arbejder med peer-feedback. I små grupper vurderes den studerende, der udfører læringsaktiviteten, ved hjælp af en rubric. De svar, der genereres sendes derefter til underviserens iPad, som får et billede af, hvilke studerende, der har brug for hjælp. Samtidig genereres individuelle rapporter til de studerende, så de kan følge deres egen progression.

\section{Evaluering af projektet}

Når laboratoriet har været i funktion i et stykke tid, vil det være relevant at evaluere de studerendes nytte af disse nye tiltag. Kategoriseringen af scenarier vil sammen med det veldefinerede formål for undervisningsaktiviteterne være muligt at anvende som en brugbar evalueringsplatform. 
Som beskrevet andre steder i litteraturen, vil det være kvalitative studier og en kvantificering af de studerendes egen vurdering af udbytte, som vil være det foretrukne studiedesign. Den kvalitative undersøgelse skal belyse hvordan lokalets muligheder benyttes af underviserne, og hvordan de enkelte undervisningsscenarier modtages af, bedømmes og motiverer de studerende. Som i andre studier vil vi være forbeholdne med at vurdere læringsudbytte direkte som bedre præstationer til eksamen, da der er mange faktorer, som kan spille en rolle dér.

Blandt undervisere vil der være en opfølgning på dels opkvalificeringsbehov, dels anvendelse af udstyr og dels en evaluering af undervisernes bedømmelse af nytteeffekt i forhold til studerendes læring og flow i undervisning i forhold til scenarierne.

\section{Overførselsværdi til andre fagområder}

Udvikling af nye teknologier og som i dette projekt ny anvendelse af kendte teknologier, giver afledte muligheder for andre områder, ikke bare inden for sundhedsvidenskab, men bredt $\mathrm{i}$ uddannelse. Brug af dette set-up af læringsteknologi kan f.eks. anvendes til kommunikationstræning, forhandling, formidling eller in vivo optagelse af konkrete færdigheder.

Dette afsnit tager afsæt i en tanke om at fjerne teknologien fra et færdighedslaboratorie og se på anvendelse i andre læringsscenarier. Det centrale i projektet er læringsaktiviteter, som de studerende udfører og kan optage digitalt. Disse optagelser kan derefter danne grundlag for analyse, refleksion og udvikling eller forbedring af færdigheder. Dermed er fokus rettet mod udvikling af færdigheder, som et centralt område.

Træning af færdigheder bruges i mange sammenhænge i uddannelse. Professionsuddannelser har helt specifikke færdigheder, som professionsudøveren må kunne for at fungere professionelt i sit arbejde (f.eks. medicin- eller sygeplejestuderende der skal anlægge perifere venekatetre). Andre fag har andre specifikke anvendelsesformål som f.eks. skrivetræning, designopgaver etc..

Flere har bekymring for, om vi med nye teknologier, er ved at udvikle undervisning til en form, hvor viden og forberedelse på mere traditionelle måder, f.eks. læsning af fagbøger træder i baggrunden. Denne diskussion er væsentlig og relevant også i forhold til dette projekt. Spørgsmålet rejser generelle didaktiske problemstillinger, som "Hvor kommer viden fra", "I hvilken form formidles viden?" osv. Derfor er det vigtigt, at anvendelsen af viden og kompetencer kombineres aktivt med øvelsen i manuelle færdigheder, når de studerende er i færdighedslaboratoriet. Således må brugen af video hele tiden ses i lyset af den pædagogiske intension, og de aktuelle læringsmål må vurderes i forhold til den måde, hvorpå de omsættes til læringsaktiviteter - kontrasten mellem delivering knowledge og aquiring knovledge. På den anden side er der også en mulighed for, at de studerende opnår bedre og mere præcise færdigheder, som er en meget central og væsentlig del af biomekanikuddannelsen. Dette sker ved en tydelig og præcis feedback til den studerendes udførelse af færdigheder. Andre læringsscenarier, der allerede optages på video kan med dette setup af teknologi måske forbedres, eller man kan via evaluering og formative prøver i undervisningsforløbene på tværs af fag få øje på områder, hvor vi kan forbedre vores design og setup.

\section{Afsluttende bemærkning}

O’Bannon et al. 2011 rammer med dette citat nogenlunde præcist, hvad vi vil med dette projekt: 
"Because the use of instructional podcasting is in its infancy, there is a need for additional research in different content areas and for longer periods of time. Students must be comfortable with the downloading procedures and accept podcasting as an instructional method. To facilitate this comfort level, instructors should frequently include podcasts in their instructional practices. In addition, students should be provided with explicit instructions on how to access and utilize the podcasts. Methods for ensuring the quality of podcast recordings should be followed by researchers who wish to create more usercentered podcasts. Future research should also address the effect that student-created podcasts have on achievement."

O’Bannon et al., 2011 (16)

Med evalueringen af initiativer, som det her beskrevne, er det vores håb, at kunne bidrage til yderligere evidens for, at læringsscenarierne kan udvikle undervisningsmodeller, der bidrager til en modernisering af mesterlæreprincipperne. Ydermere håber vi at kunne bidrage med en nuanceret brug af podcasts i undervisningen til gavn for studerendes læring af manuelle færdigheder. 


\section{Referencer}

(1) Nørgård C. , O. Graumann, P. Bollen , H.H.Lauridsen, 2013, 5I/4 Videopodcasts in a "blended learning" approach to medical skills training AMEE Conferenece abstract book p 283

(2) Elbæk, L. \& Rødbro, L. L. 2012 Elever kommunikerer gennem digital video i idræt. i Kommunikation med børn: - Leg, læring og medier i et produktperspektiv. Vestergaard, V. (red.). Første udg. Vejle: Leg og Læring - Kids n' Tweens Lifestyle v/Spinderihallerne, Kap. 3, s. 29-39 $10 \mathrm{~s}$.

(3) Lauridsen H.H.pers. comm. med http://chiro.mq.edu.au/AboutUs/facilities/

(4) Pædagogisk strategi, SDU (Pædagogisk Strategi på Det Sundhedsvidenskabelige Fakultet, Juni 2012)

(5) Bærende principper SDU (Bærende Principper for undervsining på SDU - aktiverende undervisning og aktiv læring 2013)

(6) Harden R.M., J. M. Laidlaw 2013, Be FAIR to students: Four principles that lead to more effective learning 2013, Vol. 35, No. 1 , Pages 27-31

(7) Biggs J. (1999) What the Student Does: teaching for enhanced learning, Higher Education Research \& Development, 18:1, 57-75

(8) Stephen M., M. Storr, S. Paynter, P. Morgan, Dragan Ilic 2013 Investigating the efficacy of practical skill teaching: a pilot-study comparing three educational methods Adv in Health Sci Educ (2013) 18:71-80

(9) McKenny, K. 2011. Using an online video to teach nursing skills. Teaching and Learning in Nursing (2011) 6, 172 - 175

(10) Hye og Kyong, 2014, Use of online clinical videos for clinical skills training for medical students: Benefits and challenges. BMC Medical Education 2014, 14:56

(11) Graumann, Ole - konferenceoptagelser https://www.youtube.com/watch?v=Tpse-sYcVwo

(12) Lazzari M. (2009) Creative use of podcasting in higher education and its effect on competitive agency. Computers \& Education, ISSN 0360-1315, 2009, Volume 52, Nummer 1, pp. 27 - 34

(13) Maloney S., M. Storr, S. Paynter, P. Morgan, D. Ilic 2013 The effect of student lf-video of performance on clinical skill competency: a randomised controlled trail. Adv. in health sci educ (2013) 18:81 - 89

(14) Mort J. R. og D. J. Hansen, 2010 First year pharmacy students' self-Assessment of communication skills and the impact of video revie. American journal of Pharmaceutical education2010; 74(5) Article 78

(15) O. Safir, C. K. Williams, A. Dubrowski, D. Backstein, H. Carnahan, 2013. Self-directed practice schedule enhances learning of suturing skills. J. can. Chir Vol 56 Nr 6, Dec 2013

(16) O’Bannon B. W. , J. K. Lubke, J. L. Beard, V. G. Britt, 2011. Using podcasts to replace lecture: Effects on student achievement, Computers \& Education 57 (2011) 1885-1892 


\section{Appendix 1:}

\begin{tabular}{|c|c|c|c|c|}
\hline scenarie & Formål & $\begin{array}{c}\text { Formidling- og } \\
\text { kommunikationsform }\end{array}$ & FAIR & Software og tekniske krav \\
\hline 1. & $\begin{array}{l}\text { Formålet med } \\
\text { videolektioner med og } \\
\text { uden PowerPoint er: } \\
\text { a) At formidle teoretiske } \\
\text { emner før } \\
\text { gennemgangen af en } \\
\text { færdighed } \\
\\
\text { b) At formidle udførelsen } \\
\text { af en færdighed }\end{array}$ & $\begin{array}{l}\text { Videolektioner } \\
\text { med og uden PowerPoint }\end{array}$ & $\begin{array}{l}\text { Feedback } \\
\text { a) Mulighed for spørgsmål/svar } \\
\text { på det teoretiske emne } \\
\text { b) Mulighed for feedback fra } \\
\text { underviser og medstuderende } \\
\text { på den udførte færdighed i } \\
\text { smågrupper } \\
\text { c) Peer feedback på hjemme- } \\
\text { producerede videoer } \\
\text { Aktiviteter } \\
\text { a) Forberedelse ved at læse teori } \\
\text { og se videoer. } \\
\text { b) Smågruppe aktiviteter hvor } \\
\text { de studerende øver på } \\
\text { hinanden og laver diverse } \\
\text { opgaver med video } \\
\text { c) Review af og feedback på }\end{array}$ & $\begin{array}{l}\text { I undervisningen } \\
\text { Underviser-computer med forbindelse til } \\
\text { SDU services og storskærme (via } \\
\text { videomatrix). } \\
\text { Underviser kan vælge at bruge en } \\
\text { underviserproduceret video fra } \\
\text { MediaSDU. Videoen sættes på loop på } \\
\text { undervisningscomputeren, og vises på alle } \\
\text { storskærme i lokalet. Der øves i grupper. } \\
\text { Efter undervisningen } \\
\text { Gøres brug af gruppearbejde med } \\
\text { hjemmeopgaver - se '2. Gruppearbejde } \\
\text { med video'. }\end{array}$ \\
\hline
\end{tabular}




\begin{tabular}{|c|c|c|c|c|}
\hline & & & $\begin{array}{l}\text { hjemmeproducerede videoer } \\
\text { Individualisering } \\
\text { a) Mulighed for individuel } \\
\text { feedback og læring i } \\
\text { smågrupperne } \\
\text { b) Mulighed for individuel } \\
\text { feedback på } \\
\text { hjemmeproducerede videoer } \\
\text { c) At lære tingene med flere } \\
\text { læringsressourcer og i eget } \\
\text { tempo } \\
\text { Relevans } \\
\text { a) De gennemgåede færdigheder } \\
\text { kan relateres direkte til } \\
\text { kiropraktorens kliniske virke } \\
\text { b) Underviserne har godkendt de } \\
\text { aktuelle procedurer og de } \\
\text { opfylder nationale standarder }\end{array}$ & \\
\hline 2. & $\begin{array}{l}\text { Formålet med } \\
\text { gruppearbejde med video } \\
\text { er: } \\
\text { a) At udvikle kvaliteten }\end{array}$ & $\begin{array}{l}\text { Gruppearbejde med } \\
\text { video }\end{array}$ & $\begin{array}{l}\text { Feedback } \\
\text { a) Mulighed for peer-to-peer og } \\
\text { teacher-to-peer feedback } \\
\text { b) Mulighed for selvrefleksion }\end{array}$ & $\begin{array}{l}\text { I undervisningen } \\
\text { De studerende har } 1 \text { iPad til rådighed pr. } \\
\text { par. iPads opbevares i opladningsskab og } \\
\text { fastgøres på en flexiarm med stander. } \\
\text { iPads har softwaren DigiUpload } \\
\text { installeret, således at videos kan uploades }\end{array}$ \\
\hline
\end{tabular}




\begin{tabular}{|c|c|c|}
\hline \begin{tabular}{|l} 
ved udførelsen af \\
specifikke \\
færdigheder: \\
1. Behandler og patient \\
positionering \\
2. Flow og struktur ved \\
udførelsen \\
3. Håndelag (fx \\
hastighed og \\
amplitude) \\
4. Patient håndtering \\
5. Verbal og non-verbal \\
kommunikation \\
6. Professionalisme \\
c) At udvikle \\
selvrefleksion ved \\
udførelsen af en \\
færdighed
\end{tabular} & $\begin{array}{l}\text { Aktiviteter } \\
\text { a) Forskellige former for } \\
\text { gruppearbejde, hvor alle } \\
\text { gruppemedlemmerne er } \\
\text { aktive } \\
\text { b) Review af og feedback på } \\
\text { hjemmeproducerede videoer } \\
\text { Individualisering } \\
\text { a) Mulighed for individuel } \\
\text { feedback og læring i } \\
\text { gruppearbejdet } \\
\text { b) Mulighed for individuel } \\
\text { feedback på } \\
\text { hjemmeproducerede videoer }\end{array}$ & $\begin{array}{l}\text { Når et hold har produceret en video } \\
\text { uploades den til MediaSDU, hvor den } \\
\text { deles med relevante grupper og tagges. } \\
\text { Fem videoer på 30-60 sek. kan lagres } \\
\text { lokalt på iPaden og ses på den lokale } \\
\text { storskærm. } \\
\text { Som hjemmearbejde bruger de studerende } \\
\text { MediaSDU, som giver mulighed for } \\
\text { feedback direkte på videoerne og i } \\
\text { kommentarfelt af de valgte grupper og } \\
\text { underviserne. } \\
\text { Gruppearbejdet er normeret til ca. } 20 \text { min. }\end{array}$ \\
\hline
\end{tabular}




\begin{tabular}{|c|c|c|c|c|}
\hline & af en færdighed & & $\begin{array}{l}\text { Relevans } \\
\text { a) Gruppearbejdet vil reflektere } \\
\text { vigtige færdigheder, den } \\
\text { studerende kan relatere direkte } \\
\text { til kiropraktorens kliniske virke }\end{array}$ & $\begin{array}{l}\text { Efter undervisningen } \\
\text { Gives hjemmeopgaver, har de studerende } \\
\text { mulighed for at bruge } \\
\text { færdighedslaboratoriet } 24 / 7 \text {. } \\
\text { Hjemmeopgaven løses ved brug lokalets } \\
\text { standere og de studerendes egne tablets, } \\
\text { iPads eller smartphones. }\end{array}$ \\
\hline 3. & $\begin{array}{l}\text { Formålet med den } \\
\text { løbende supervisering } \\
\text { med video er: } \\
\text { a) At foretage en } \\
\text { formativ evaluering af } \\
\text { de opnåede } \\
\text { færdigheders kvalitet i } \\
\text { forhold til: } \\
\text { 1. Behandler og patient } \\
\text { positionering } \\
\text { 2. Flow og struktur ved }\end{array}$ & $\begin{array}{l}\text { Løbende supervisering } \\
\text { med video }\end{array}$ & $\begin{array}{l}\text { Feedback } \\
\text { a) Underviser feedback på } \\
\text { styrker/svagheder ved en } \\
\text { given færdighed } \\
\text { b) Bestået/ikke bestået } \\
\text { supervision ud fra fastlagte } \\
\text { evalueringskriterier } \\
\text { Aktiviteter } \\
\text { a) Forberedelse og } \\
\text { perfektionering af }\end{array}$ & $\begin{array}{l}\text { Efter undervisningen } \\
\text { Den løbende supervisering med video } \\
\text { foregår som beskrevet under '2. } \\
\text { Gruppearbejde med video' > 'Efter } \\
\text { undervisningen' } \\
\text { De uploadede videoer tagges med } \\
\text { 'Supervisering nr. x', således at } \\
\text { underviser hurtigt kan tilgå videoerne, } \\
\text { give feedback og godkende/ikke } \\
\text { godkende superviseringen. }\end{array}$ \\
\hline
\end{tabular}




\begin{tabular}{|c|c|}
\hline 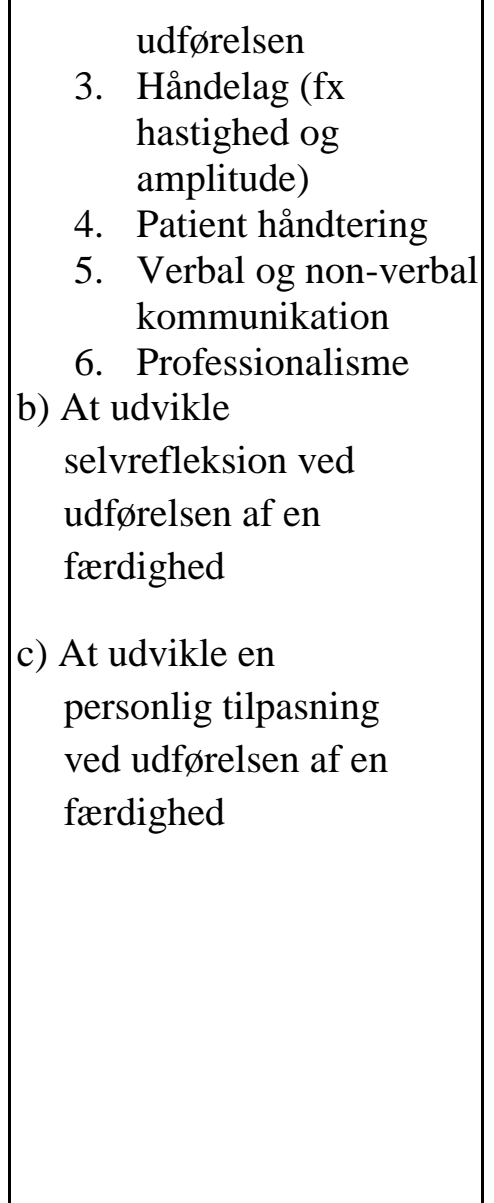 & $\begin{array}{l}\text { færdigheder } \\
\text { b) Smågruppe aktiviteter hvor } \\
\text { de studerende reviewer og } \\
\text { kritisk tager stilling til de } \\
\text { gennemgåede færdigheder og } \\
\text { slutteligt producerer og } \\
\text { afleverer 'den bedste video' } \\
\text { Individualisering } \\
\text { a) Individuel feedback fra } \\
\text { underviser på den } \\
\text { producerede supervision } \\
\text { Relevans } \\
\text { a) De erhvervede kliniske } \\
\text { færdigheder kan relateres } \\
\text { direkte til kiropraktorens }\end{array}$ \\
\hline
\end{tabular}




\begin{tabular}{|c|c|c|c|c|}
\hline & & & kliniske virke & \\
\hline 4. & $\begin{array}{l}\text { Formålet med at } \emptyset \text { ve på } \\
\text { egen hånd med video er: } \\
\text { a) At udvikle kvaliteten } \\
\text { af specifikke } \\
\text { færdigheder ved } \\
\text { selvrefleksion af: } \\
\text { 1. } \text { Behandler og patient } \\
\text { positionering } \\
\text { 2. } \text { Flow og struktur ved } \\
\text { udførelsen } \\
\text { 3. Håndelag (fx } \\
\text { hastighed og } \\
\text { amplitude) } \\
\text { 4. Patient håndtering } \\
\text { 5. Verbal og non-verbal } \\
\text { kommunikation } \\
\text { 6. Professionalisme }\end{array}$ & $\begin{array}{l}\text { Øvning på egen hånd } \\
\text { med video }\end{array}$ & $\begin{array}{l}\text { Feedback } \\
\text { a) Mulighed for peer-to-peer } \\
\text { feedback på færdigheder } \\
\text { optaget på video } \\
\text { b) Mulighed for selvrefleksion } \\
\text { på egne færdigheder } \\
\\
\text { Aktiviteter } \\
\text { a) Optager færdigheder på video } \\
\text { med gennemsyn af lokalt } \\
\text { lagret video på den lokale } \\
\text { storskærm - mulighed for } \\
\text { refleksion/ perfektionering af } \\
\text { færdigheden og/eller } \\
\text { feedback muligheder }\end{array}$ & $\begin{array}{l}\text { De studerende har mulighed for at bruge } \\
\text { færdighedslaboratoriet } 24 / 7 \text {. } \\
\text { Her kan de logge på MediaSDU med egne } \\
\text { tablets, iPads eller smartphones og: } \\
\text { a) Se underviserproducerede videos } \\
\text { b) Se og producere egne videos } \\
\text { c) Se andre gruppers videos på en } \\
\text { udvalgt storskærm }\end{array}$ \\
\hline
\end{tabular}




\begin{tabular}{|c|c|}
\hline $\begin{array}{l}\text { b) At udvikle en } \\
\text { personlig tilpasning } \\
\text { ved udførelsen af en } \\
\text { færdighed } \\
\\
\text { c) At den studerende kan } \\
\text { få feedback på } \\
\text { udførelsen af sin } \\
\text { færdigheder af } \\
\text { underviser/medstudere } \\
\text { nde og derigennem } \\
\text { dygtiggøre sig }\end{array}$ & $\begin{array}{l}\text { Individualisering } \\
\text { a) Den studerende } \\
\text { optager/producerer selv } \\
\text { videoen med dygtigg ørelse } \\
\text { og bevidstgørelse som } \\
\text { formål. Den studerende kan } \\
\text { derefter yderligere opsøge } \\
\text { feedback }\end{array}$ \\
\hline
\end{tabular}




\section{Overskrift type 1}

Brødtekst. Quisque nisl erat, auctor quis, bibendum eu, faucibus non, ante. Mauris cursus ultricies nunc. Fusce mattis enim. Fusce nibh turpis, pellentesque sed, bibendum eu, imperdiet in, quam. Mauris quis urna id odio suscipit lacinia. Integer nulla nibh, cursus eget, rhoncus nec, lacinia ut, dolor. Praesent sed turpis nec pede dictum pharetra. Sed in massa vitae velit euismod porttitor. Sed in metus vel augue iaculis sollicitudin. Nam consectetur volutpat turpis. Maecenas rutrum, tellus et ultrices dapibus, arcu tellus sagittis odio, eu scelerisque velit ligula convallis urna. Proin tincidunt congue risus. Vestibulum ante ipsum primis in faucibus orci luctus et ultrices posuere cubilia Curae; Sed tincidunt magna sed nibh. Maecenas vehicula gravida nunc.

"Et citat skal ombrydes på denne måde og forfatteren skal listes nedenfor."

(Burchardt 2007: 22)

Brødtekst. Lorem ipsum dolor sit amet, consectetur adipiscing elit. Phasellus at purus. Sed quis odio ut neque dapibus pulvinar.

Pellentesque libero. Sed consequat. Suspendisse luctus tellus eget elit. Aliquam eget odio. Ut luctus, nunc vitae ornare pretium, nulla ipsum fermentum ligula, ac tincidunt pede libero non nulla. Integer hendrerit lorem vitae nisi. Vestibulum quam pede, volutpat non, fermentum in, rhoncus ac, lorem. Sed diam leo, porttitor quis, semper sed, rhoncus sed, erat. 
Overskrift type 2

Brødtekst. Quisque nisl erat, auctor quis, bibendum eu, faucibus non, ante. Mauris cursus ultricies nunc. Fusce mattis enim. Fusce nibh turpis, pellentesque sed, bibendum eu, imperdiet in, quam. Mauris quis urna id odio suscipit lacinia. Integer nulla nibh, cursus eget, rhoncus nec, lacinia ut, dolor.

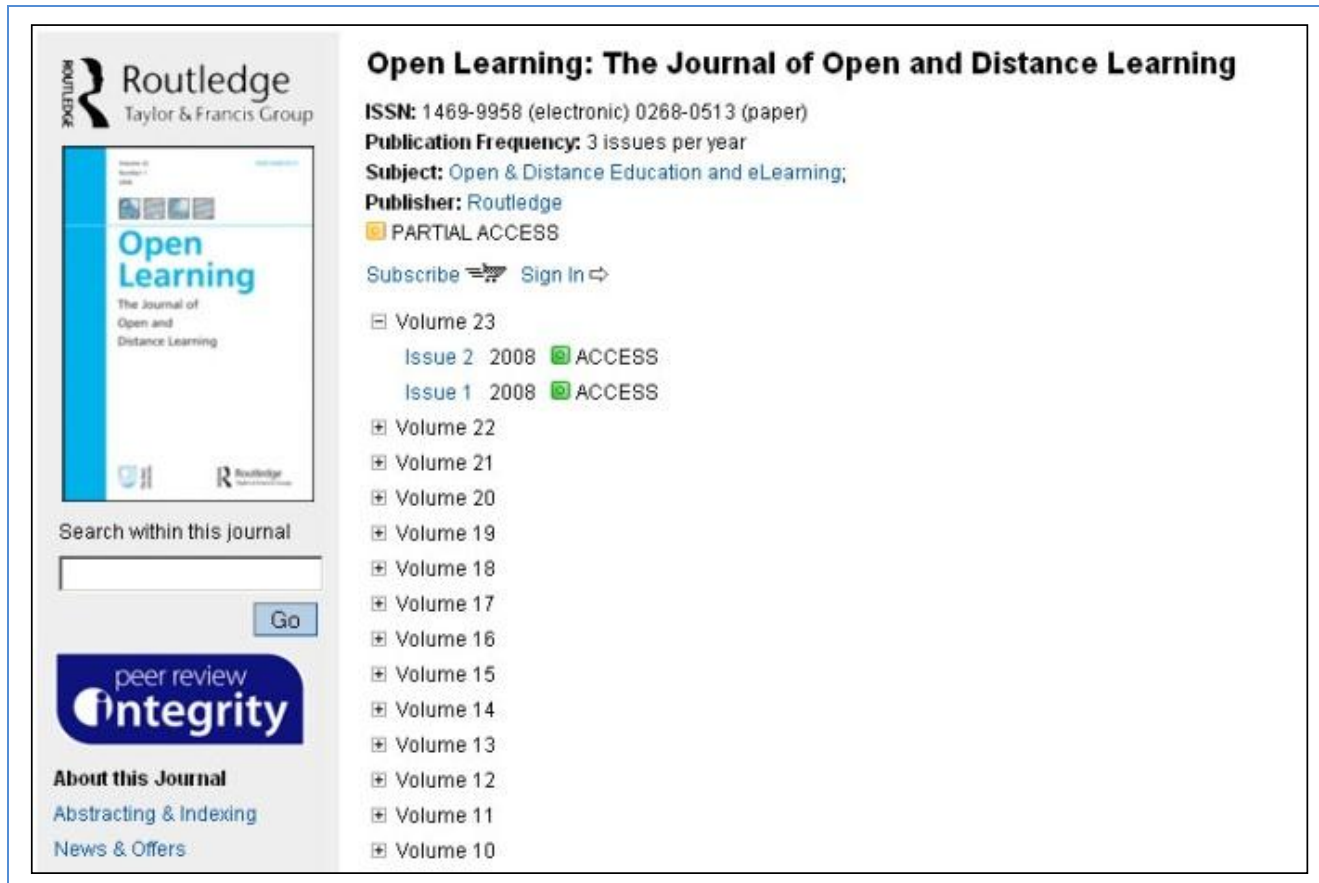

Figur 5. Eksempel på en figur med tilhørende link. http://www.informaworld.com/smpp/title content=t713440064 db=all). 


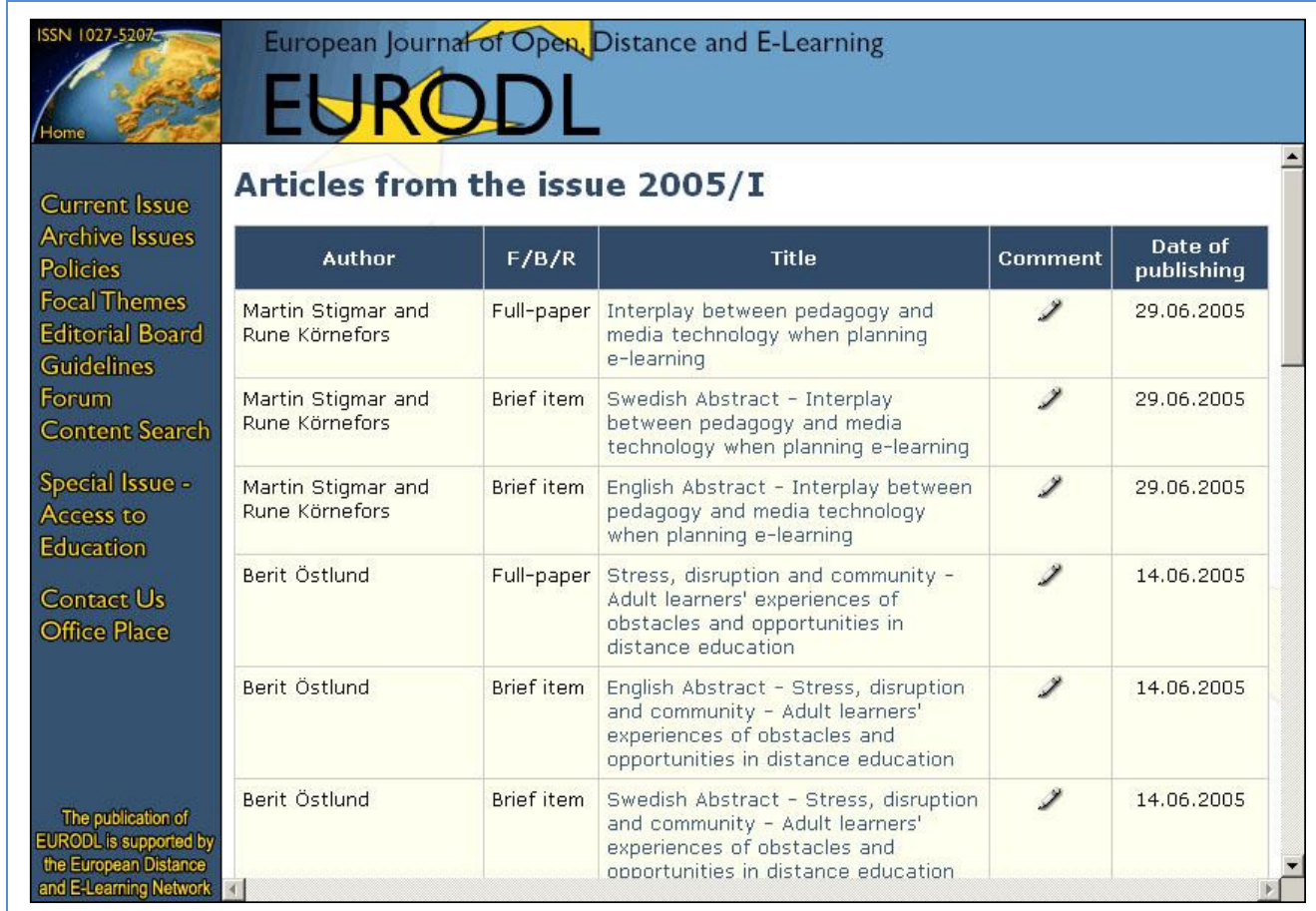

Figur 6. Eksempel på en figur med tilhørende link www.eurodl.org 


\section{Referencer}

Forfatterefternavn, Forfatter fornavn. (Årstal). Bogens fulde titel, eventuelle sideangivelser.

Bang, J. (2000). Distribueret Uddannnelse, Om dialog, refleksion og fleksibilitet i IKT-støttet læring, I: Heilesen, S. (red.). At Undervise med IKT, Samfundslitteratur, s. 195-216.

Bang, J. (2004). Hvorfor er vidensdeling så svært? - om vidensorganisering og læring som kommunikation. I: Heilesen, S. (red.): Det digitale nærvær. Viden og design i nye medier, Roskilde Universitetsforlag, s. 13-31. 